\title{
Understanding the Behavioral Intention to Use a University Web-Portal
}

\author{
Ezra Aditia ${ }^{1, *}$, I Nengah Tela ${ }^{1}$, Nursyam Saleh ${ }^{1,}$, Desi Ilona ${ }^{2}$, and Zaitul ${ }^{3}$ \\ ${ }^{1}$ Civil Engineering and Planning Faculty, Universitas Bung Hatta, Padang 25133, Indonesia \\ ${ }^{2}$ Economics Faculty, Universitas Putra Indonesia YPTK, Padang 25221, Indonesia \\ ${ }^{3}$ Economics Faculty, Universitas Bung Hatta, Padang 25133, Indonesia
}

\begin{abstract}
Behavioral intention to use the information technology is a predictor of behavioral to use it. There are several studies investigating the effect of factors from Technology Acceptance Model (TAM) on attitude toward use and its effect on behavioral intention to use which based on Theory of Plan Behavior (TPB). However, there is a limited studies emphasizing on academic portal in a university. Therefore, this study investigates the effect of perceived ease of use (PEU) and perceived usefulness(PU) on attitude toward use (ATU) and Behavioral intention to use (BIU). Further, this study also aims to determine the relationship between attitude toward use (ATU) and behavioral intention to use (BIU). Using 123 registered students in four faculties, smart path least square (PLS) is applied to analysis the data. The findings show that PEU has a positive significant relationship with BIU and ATU. In addition, ATU also has a significant positive effect on BIU. However, PU do not have a significant relationship with BIU and ATU. This study has practical and theoretical implication and it discuss in detail in paper.
\end{abstract}

\section{Background of Study}

A modern higher education system is needed for a modern society. It focuses on knowledge management, lifelong learning and information technology. University as center of knowledge should have a good management practice. One of management aspects that must be covered by university is technology and information (TI), such as internet. Internet technology play an important role to support the learning process in a University. Universitas Bung Hatta (UBH), one of the biggest private university in Indonesia, has developed a management information system, including academic information system (academic portal; portal.bunghatta.ac.id). Analog with library portal, academic portal is a customized, personalized and integrated information service to aggregate all kinds of academic resources and services through a single access and management point for users[1]. In academic portal, there are several information needed by university stakeholders. This portal can be assessed by students, lecturers, administration staffs, and managers (Rector, vice rector, dean, head department etc.). To access the portal, University also provide students and other stakeholders with Wi-Fi. However, students always complain with academic portal. IT department report

\footnotetext{
* Corresponding author: adi@bunghatta.ac.id
} 
that there is low rate of using this portal to get academic and non-academic resources from university. In addition, there is no conclusive answer why students have low rate of using the university portal.

Theoretically, there are several theories why it happens. Technology Acceptance Model (TAM) is one of theories why acceptance or use of technology vary among individual [2]. Ease of use and perceived usefulness are factors affecting the acceptance of technology.[3]conclude that TAM is useful model to describe the behavior of technology use in Canada. In addition, [4]conclude that social influence and cognitive instrumental process have a significant effect on use acceptance in US. [5] study of behavioral intention to use the hotel internet application. The determinants of intention are an ease of use, usefulness, credibility and subjective norm in US. [6] examine the relationship between e-satisfaction and e-retention in e-learning context of United Emirate Arab (UEA). [7] confirm that the explanatory power of TAM in adoption of social network in Portugal.[8]found that attitude toward usage and subjective norm significantly influence the behavioral attention to use the technology. [9] investigate the effect of perceived privacy and government support on the intention to use internet banking services in Indonesia.[10]study an internet adoption and use among men and women among Indonesia's students. Finally, [11]study an internet cafe users in Indonesia.

However, less attention has been paid this issue in higher education institution, such University. [12] state that Education institution is a potential key to fostering greater internet use and large body of research has addressed the psychological variables that influence technology use or non-use, such as academic portal. In addition, the developing countries have benefited from the internet or IT in general and it, however, has receiveda little research attention [12]. According to[2], there are several determinants of the attitude toward use of Technology : ease of use and perceived usefulness. Therefore, this study investigates the effect of Perceived-Ease of Use (PEU) and Perceived Usefulness (PU) on Attitude Toward Use (ATU) of academic portal (see figure 1). Further, it also examine the relationship between attitude toward use (ATU) and Behavioral Intention to Use(BIU) an academic portal(see figure 1) that suggested by Theory of Plan Behavior[13]. This study differs from study of [14]where they study based on TAM, this study use two theory: TAM and TPB. Therefore, this studies combine two theories: Technology Acceptance Model (TAM) and Theory of Plan Behavior (TPB) in context of university students. This study contribute to the theory of TAM [2], [4] and TPB[13]. Therefore, this studies have practical implication in the sense that University can use the findings for IT related decision to improve student's performance.

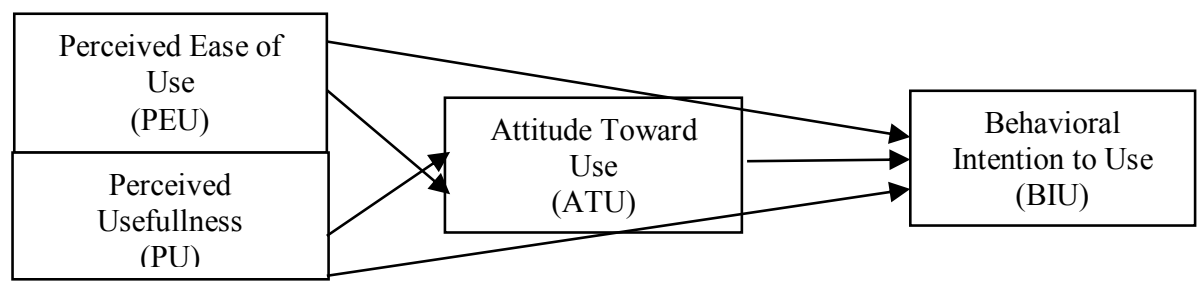

Fig. 1. Conceptual Model.

[12] argue that perceived usefulness refers to the expectation that the technology will enhance one's job performance and perceived ease of use defined as belief that using the technology will be free of efforts. Thus, [8]defined the attitude toward use as the way individuals respond to and are disposed towards an object. Behavioral intention to use is defined as strength of one's intention to perform a specified behavior[10]. 


\section{Methodology}

UBH has seven faculties with more than 8700 registered in 2018. This study uses the students in four faculties in UBH, i.e. Economics, Education, Law and Humanities. Convenient sampling method is applied in this study. A structured questionnaire was designed and implemented in the context of university portal. All construct measurement was adapted from[7]. Each item in questionnaire is constructed as follows: (i) Three items for BIU, (ii) Three items for ATU, (iii) seven items for PU and (iv) five items for PEU. Five-point Likert scale was used to measure the respondents' perception on the survey question. Data was analyzed using smart-pls. There are two analyses: measurement and structural model. There are four criteria's for measurement model [15] : (i) indicator reliability (using outer loadings, $>0.70$ ), (ii) internal consistency (using composite reliability and Cronbach alpha, $>0.70$ ) (iii) convergent validity (using AVE, > 0.50), and (iv) discriminant validity (using Fornell-Lacker criterion, greater than its cross loading). In addition, there are two criteria for structural model [15]: (i) predictive relevance (using Q-square, > 0), and (ii) Predictive power (using Rsquare). The objective of research is answered by assessing the significance of structural path coefficients: (i) 1.65 for $10 \%$, (ii) 1.96 for $5 \%$ and (iii) 2.58 for $1 \%$.

\section{Result and discussion}

Students in four faculties are object of studies. 150 questionnaires were distributed and the researcher managed to collect 135(return rate of 90\%). During screening, 12 incomplete questionnaires was excluded from analysis. Demographic analysis of respondent from gender, female students are 70 students or $56.90 \%$ and the rest is male student $(43.10 \%)$. According to respondent's age, student with age of 18 to 20 years is 55 students or $44.72 \%$, followed by 60 or $48.78 \%$ are student with age of 21 to 23 years. Further, 8 students $(6.50 \%)$ are greater than 23 years old. However, majority of respondents are from faculty of economics $(54.50 \%)$, followed by education $(29.30 \%)$, law (10.60\%) and humanity $(5.70 \%)$.

\subsection{Analysis of measurement model}

The result of measurement model is shown in Table 1. [16]state that the validity of measurement model depends on the indicator loadings, Cronbach alpha (CA), construct reliability (CR), average variance extracted (AVE) and discriminant validity. The result show that indicator loading for all items are greater than 0.7 and it can conclude that all items surpass the cut off level [17]. In addition, result of reliability test is also achieved the criteria because the value of Cronbach's alpha and composite reliability are greater than the threshold level of 0.7 . further, the result of convergent validity which applied the average variance extracted (AVE) also indicate more than 0.5.

The last criteria are discriminant validity. This kind of validity is assessed by using the Fornell-Lacker analysis. This value is created through square root of the AVE for each construct. Decision whether construct is valid or not by comparing this value with other constructs. All constructs have a satisfied discriminant validity because all value of square root of AVE each constructs is higher. For example, square root of BIU's AVE is 0.707601, which is greater than correlation between BIU \& ATU (0.653447), BIU\& PEU (0.663595), and BIU \& PU (0.469327). 
Table 1. Measurement Model.

\begin{tabular}{|c|c|c|c|c|c|}
\hline Construct & Item & Loadings & CA & $\mathrm{CR}$ & AVE \\
\hline \multirow{3}{*}{ BIU } & biu_1 & 0.766297 & \multirow{3}{*}{0.714121} & \multirow{3}{*}{0.839807} & \multirow{3}{*}{0.636255} \\
\hline & biu 2 & 0.827066 & & & \\
\hline & biu_3 & 0.798446 & & & \\
\hline \multirow{3}{*}{ ATU } & atu 1 & 0.798663 & \multirow{3}{*}{0.782333} & \multirow{3}{*}{0.873484} & \multirow{3}{*}{0.697436} \\
\hline & atu_2 & 0.879254 & & & \\
\hline & atu_3 & 0.825443 & & & \\
\hline \multirow{5}{*}{ PEU } & peu_1 & 0.824804 & \multirow{5}{*}{0.859955} & \multirow{5}{*}{0.899821} & \multirow{5}{*}{0.899821} \\
\hline & peu_2 & 0.715683 & & & \\
\hline & peu_3 & 0.862417 & & & \\
\hline & peu_4 & 0.78361 & & & \\
\hline & peu_5 & 0.816111 & & & \\
\hline \multirow{7}{*}{ PU } & $\mathrm{pu} \_1$ & 0.764462 & \multirow{7}{*}{0.910676} & \multirow{7}{*}{0.929165} & \multirow{7}{*}{0.929165} \\
\hline & pu_2 & 0.810103 & & & \\
\hline & pu_3 & 0.773517 & & & \\
\hline & pu_4 & 0.852532 & & & \\
\hline & pu_5 & 0.882891 & & & \\
\hline & pu 6 & 0.748115 & & & \\
\hline & pu 7 & 0.81503 & & & \\
\hline
\end{tabular}

\subsection{Analysis of Structural model}

The result of structural model is demonstrated in Table 4. The overall explanatory power ( $R$ square) show that the model accounts for $42.69 \%$ and $40.92 \%$ of BIU and ATU respectively. In addition, second assessment is Q square. Q square is 0.27 for BIU and 0.25 for ATU respectively. These value is more than zero, which satisfy the model's predictive validity [16]. Based on the path coefficient and $t$ value, three constructs have a significant relationship: (i) perceived ease of use (PEU) and attitude toward use (ATU), (ii) Perceived ease of use (PEU) and BIU, and (iii) attitude toward use (ATU) and BIU.

Table 3. Structural Model Analysis.

\begin{tabular}{|c|c|c|c|c|c|}
\hline $\begin{array}{c}\text { Endogenous } \\
\text { Construct }\end{array}$ & R-Squared & Q-Squared & Relation & $\begin{array}{c}\text { Path } \\
\text { Coefficient }\end{array}$ & T Value \\
\hline BIU & 0.426993 & 0.270757 & ATU -> BIU & 0.379359 & $3.707242^{* * *}$ \\
\hline ATU & 0.409186 & 0.254627 & PEU -> BIU & 0.428289 & $3.038777^{* * *}$ \\
\hline & & & PEU -> ATU & 0.638142 & $4.854615^{* * *}$ \\
\cline { 4 - 6 } & & & PU -> BIU & 0.001302 & 0.011789 \\
\cline { 4 - 6 } & & & PU -> ATU & 0.001055 & 0.007794 \\
\hline
\end{tabular}

Notes: $* * *$ indicate a significant at $1 \%$

PEU has a significantly positive relationship with ATU of academic portal. It means that the higher the PEU, the better ATU of academic portal. This finding is consistent with result of Pinho \& Soares (2011). In addition, there is also a positive significant relationship between PEU and BIU the academic portal. This finding is aligned with evidence of [5]. Further, the effect of ATU on BIU is positive significant. The better the ATU of academic portal, the higher BIU. This result is supported by [8]. However, the effect of PU on ATU and BIU are not significant and this findings are not consistent with finding of [7], [8]. In brief, these findings confirm that TAM is partially explain the technology acceptance among university students. Thus, it also confirms that the relationship between attitude toward use and behavioral intention to use is underpinned by Theory of Plan Behavior. 


\section{Conclusion}

The important of university portal, such as academic portal, has been documented by several researchers. This study investigates the effect of Perceived Usefulness (PU) and PerceivedEase of Use (PEU) on Attitude Toward Use (ATU) and the relationship between ATU and Behavioral Intention to Use (BIU). Students from four faculties are as research object. The findings show that PEU has a significant relationship with ATU and BIU. In addition, ATU also has a positive effect on BIU. This study has a theoretical and practical implications. This study contributes the TAM and TPB. These findings also could be used by university manager to design, revise, and develop the academic portal. This study has limitation in the sense that there is a limited data (only 123 students) and do not investigate the role of ATU as mediating variable. there is some avenue for future researchers who interested in this topic. They can add more respondents and testing the mediating role of ATU between PEU \& PU and BIU.

\section{References}

1. M. N. Masrek, A. Jamaludin, and S. A. Mukhtar, . Libr. Rev., vol. 59, no. 3, pp. 198212 (2010)

2. F. D. Davis, Int. J. Man-Machine Stud., vol. 38, pp. 475-487, (1993)

3. P. Legris, J. Ingham, and P. Collerette, Inf. Manag., vol. 40, pp. 191-204 (2003)

4. V. Venkatesh and F. D. Davis, Manage. Sci., vol. 46, no. 2, pp. 186-204 (2000)

5. J. S. Kim, Int. J. Contemp. Hosp. Manag., vol. 28, no. 8, pp. 1535-1553 (2016)

6. M. A. Al-hawari and S. Mouakket, Educ. Bus. Soc. Contemp. Middle East. Issues, vol. 3, no. 4, pp. 299-314 (2010)

7. J. C. M. R. Pinho and A. M. Soares, J. Res. Interact. Mark., vol. 5, no. 2/3, pp. 116-129 (2011)

8. T. Teo and C. B. Lee, Campus-Wide Inf. Syst., vol. 27, no. 2, pp. 60-67 (2010)

9. A. Susanto, H. Lee, H. Zo, and A. P. Ciganek, Inf. Dev., vol. 29, no. 4, pp. 309-322 (2012)

10. F. Wahid, Electron. J. Inf. Syst. Dev. Ctries., vol. 32, no. 6, pp. 1-8 (2007)

11. B. Furuholt, S. Kristiansen, and F. Wahid, Electron. J. Inf. Syst. Dev. Ctries., vol. 22 , no. 3, pp. 1-16 (2005)

12. M. Fusilier and S. Durlabhji, Campus-Wide Inf. Syst., vol. 22, no. 4, pp. 233-246 (2005)

13. I. Ajzen, Organ. Behav. Hum. Decis. Proccess, vol. 50, pp. 179-211 (2013)

14. T. Handayani, Kusrini, and A. Sunyoto, Angkasa, vol. 5, no. 1, pp. 63-74 (2013)

15. V. E. Vinzi, W. W. Chin, J. Henseler, and H. Wang, Handbook of Partial Least Square: Concepts, Methods and Applications. Berlin, German: Springer (2010)

16. J. F. Hair, G. T. M. Hult, C. M. Ringle, and M. Sarstedt, A Primer on Partial Least Squares Structural Equation Modeling (PLS-SEM). Thousand Oaks: Sage (2013)

17. J. F. Hair, C. M. Ringle, and M. Sarstedt, J. Mark. Theory Pract., vol. 19, no. 2, p. 2011 (2011) 